\title{
Challenges in electrochemical remediation of chlorinated solvents in natural groundwater aquifer settings
}

Hyldegaard, Bente Højlund; Jakobsen, Rasmus; Weeth, Eline; Overheu, Niels; Gent, David; Ottosen, Lisbeth $M$.

Published in:

Journal of Hazardous Materials

Link to article, DOI:

10.1016/j.jhazmat.2018.12.064

Publication date:

2019

Document Version

Peer reviewed version

Link back to DTU Orbit

Citation (APA):

Hyldegaard, B. H., Jakobsen, R., Weeth, E., Overheu, N., Gent, D., \& Ottosen, L. M. (2019). Challenges in electrochemical remediation of chlorinated solvents in natural groundwater aquifer settings. Journal of Hazardous Materials, 368, 680-688. https://doi.org/10.1016/j.jhazmat.2018.12.064

\section{General rights}

Copyright and moral rights for the publications made accessible in the public portal are retained by the authors and/or other copyright owners and it is a condition of accessing publications that users recognise and abide by the legal requirements associated with these rights.

- Users may download and print one copy of any publication from the public portal for the purpose of private study or research.

- You may not further distribute the material or use it for any profit-making activity or commercial gain

- You may freely distribute the URL identifying the publication in the public portal 


\section{Accepted Manuscript}

Title: Challenges in electrochemical remediation of chlorinated solvents in natural groundwater aquifer settings

Authors: Bente H. Hyldegaard, Rasmus Jakobsen, Eline

Weeth, Niels Overheu, David Gent, Lisbeth Ottosen

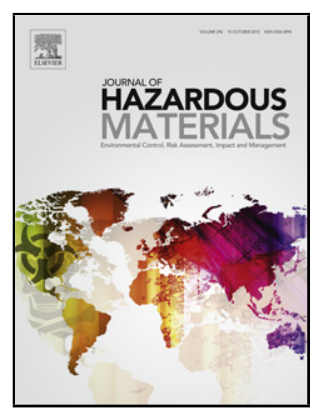

PII:

S0304-3894(18)31213-5

DOI: https://doi.org/10.1016/j.jhazmat.2018.12.064

Reference: HAZMAT 20098

To appear in: Journal of Hazardous Materials

Received date: $\quad 1$ September 2017

Revised date: 9 December 2018

Accepted date: 17 December 2018

Please cite this article as: Hyldegaard BH, Jakobsen R, Weeth E, Overheu N, Gent $\mathrm{D}$, Ottosen L, Challenges in electrochemical remediation of chlorinated solvents in natural groundwater aquifer settings, Journal of Hazardous Materials (2018), https://doi.org/10.1016/j.jhazmat.2018.12.064

This is a PDF file of an unedited manuscript that has been accepted for publication. As a service to our customers we are providing this early version of the manuscript. The manuscript will undergo copyediting, typesetting, and review of the resulting proof before it is published in its final form. Please note that during the production process errors may be discovered which could affect the content, and all legal disclaimers that apply to the journal pertain. 


\title{
Challenges in electrochemical remediation of chlorinated solvents in natural groundwater aquifer settings
}

Bente H. Hyldegaard ${ }^{1,2, *}$, Rasmus Jakobsen ${ }^{3}$, Eline Weeth ${ }^{1}$, Niels Overheu ${ }^{4}$, David Gent ${ }^{5}$, Lisbeth Ottosen ${ }^{2}$

${ }^{1}$ COWI A/S, Department of Waste and Contaminated Sites, 2800 Kongens Lyngby, Denmark ${ }^{2}$ DTU (Technical University of Denmark), Department of Civil Engineering, 2800 Kongens Lyngby, Denmark

${ }^{3}$ GEUS, Department of Geochemistry, 1350 København K, Denmark

${ }^{4}$ CRD (Capital Region of Denmark), Centre for Regional Development, 3400 Hillerød, Denmark

${ }^{5}$ USACE (US Army Corps of Engineers), Engineer Research and Development Center, 39180 Mississippi, United States

* Corresponding author: COWI A/S, department of Waste and Contaminated Sites, Parallelvej 2, 2800 Kongens Lyngby, Denmark. Direct: +45 564087 70. E-mail address: behd@cowi.com.

\section{Graphical abstract}

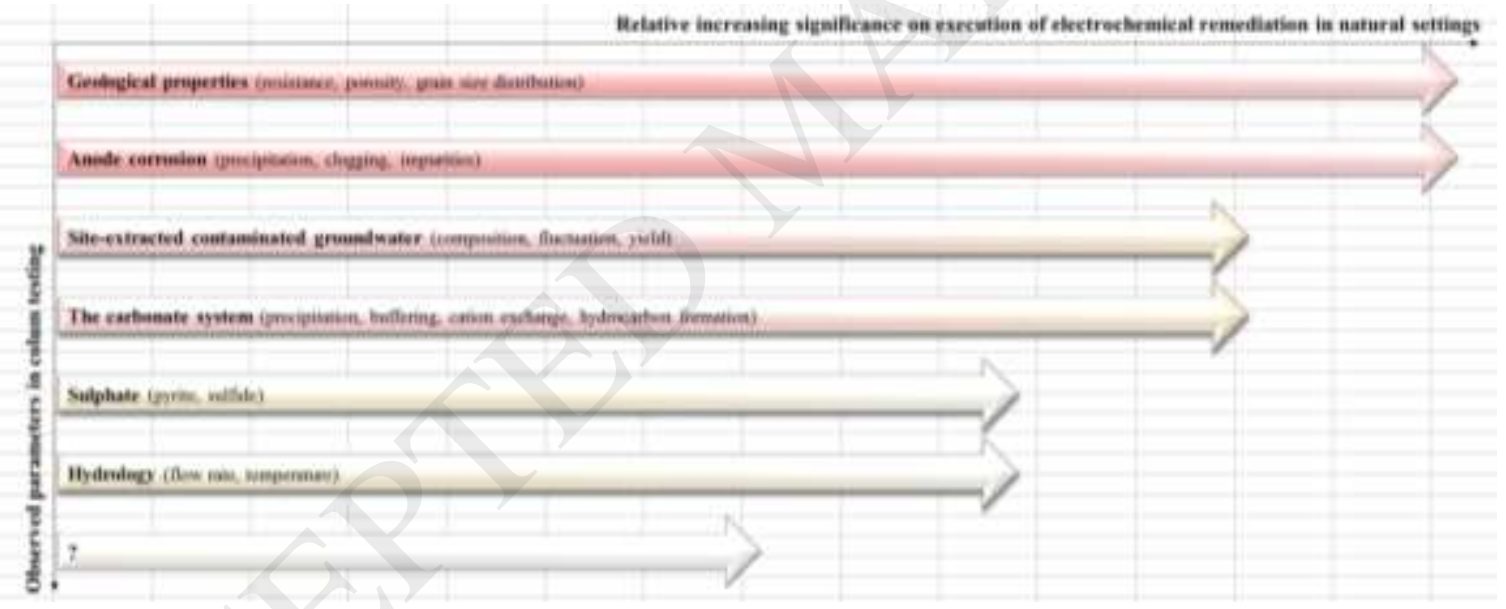

\section{Highlights:}

- Identification of knowledge gaps in applied in situ electrochemical remediation

- High complexity using natural geology and field-extracted contaminated groundwater

- Corrosion of the cast iron anode prompted significant precipitation of iron oxides

- A simple geochemical model captured the overall observed system response

- Rankings of parameter influence on the execution of electrochemical remediation

\begin{abstract}
Establishment of electrochemical zones for remediation of dissolved chlorinated solvents in natural settings was studied. An undivided 1D-experimental column set-up was designed for the assessment of the influence
\end{abstract}


of site-extracted contaminated groundwater flowing through a sandy aquifer material, on the execution of laboratory testing. A three-electrode system composed of palladium coated pure iron cathodes and a cast iron anode was operated at $12 \mathrm{~mA}$ under varying flow rates. The natural settings added complexity through a diverse groundwater chemistry and resistance in the sand. In addition, significant precipitation of iron released through anode corrosion was observed. Nevertheless, the complex system was successfully modelled with a simple geochemical model using PHREEQC. A ranking of the significances of system parameters on the laboratory execution of electrochemical remediation in natural settings was proposed: Geological properties > anode corrosion > site-extracted contaminated groundwater $>$ the carbonate system $>$ sulphate $>$ hydrology $>$ less significant unidentified parameters. This study provides insight in actual challenges that need to be overcome for in situ electrochemical remediation.

Keywords: Electrochemical, geology, groundwater, modelling, ranking

\section{Introduction}

Chlorinated solvents threaten groundwater resources. The widespread contamination by chlorinated solvents is a relic from the past with extensive use of tetrachloroethylene (PCE) and trichloroethylene (TCE) in e.g. dry-cleaning facilities and metal processing [1]. The chlorinated solvents and their chlorinated degradation products are acute toxic and carcinogenic [2]. Furthermore, the compound's high solubility, volatility and low sorption to sediments challenge the current treatment systems. Thus, optimised means of protecting the groundwater from these contaminants are important. Pump-and-treat (P\&T) systems are commonly used to keep plumes from reaching water supply wells. However, these treatment facilities are long-term solutions with substantial operation and maintenance requirements. In addition, the P\&T plants are challenged by weak sorption of the chlorinated degradation products to the activated carbon.

We propose, as an alternative to P\&T, establishment of an electrochemical zone for in situ degradation of PCE and degradation products. Hence, the focus of this study is on application and combination of the different electrochemical processes to optimise the electrochemical zone for complete degradation of chlorinated solvents in natural groundwater settings. This is vital for proving the methods applicability. Following a successful adaption to field settings, electrochemical remediation is considered superior to P\&T facilities even in high-permeability zones, because i) chlorinated parent components and chlorinated degradation products can be equally targeted, ii) no hazardous waste is generated, iii) the electrochemical remedy can be installed fully underground, i.e. site-activities can resume, and iv) the carbon footprint is lower.

It is known that i) fast electrochemical reduction of chlorinated solvents near the electrodes can be obtained [3] and ii) reactants can be generated, and subsequently reduce or oxidise the chlorinated solvents [4]. Thus, the treatment can be designed without addition of e.g. substrate or generation of waste products like spent activated carbon.

\subsection{Knowledge gaps}

Undivided flow-through cells operated with solid-state electrodes under constant current simulate realistic field scale designs for remediation in primary aquifers. Studies assessing degradation of chlorinated solvents in such systems have focused on the significance of electrode composition, configurations and system parameters such as current density and flow rate (Table 1).

Table 1. Summary of electrochemical remediation of dissolved chlorinated solvents in undivided cells under constant current with solid-state electrodes 


\begin{tabular}{llll}
\hline Experimental design ${ }^{1,2,3}$ & $\begin{array}{l}\text { Power } \\
\text { supply }\end{array}$ & $\begin{array}{c}\text { Target Findings } \\
\text { conta- } \\
\text { minant }\end{array}$ & $\begin{array}{l}\text { Refe- } \\
\text { rence }\end{array}$ \\
\hline
\end{tabular}

Fluid: Synthetic

Geology: Limestone gravel

Configuration: $\mathrm{A} \rightarrow \mathrm{C} \rightarrow \mathrm{A}$

Anode: Cast Fe, MMO

Cathode: $\mathrm{Cu}$

Catalyst: -

Fluid: Synthetic

Geology: "Glass beads"

Configuration: $\mathrm{C} \rightarrow \mathrm{C} \rightarrow \mathrm{A}$,

$\mathrm{A} \rightarrow \mathrm{C}, \mathrm{C} \rightarrow \mathrm{A}$

Anode: $\mathrm{MMO}$, cast $\mathrm{Fe}$

Cathode: MMO, cast Fe

Catalyst: $\mathrm{Pd} / \mathrm{C}, \mathrm{Pd} / \mathrm{Al}$

pellets

Fluid: Synthetic

Geology: "Glass beads"

Configuration: $\mathrm{A} \rightarrow \mathrm{C} \rightarrow \mathrm{C}$

Anode: MMO

Cathode: MMO

Catalyst: $\mathrm{Pd} / \mathrm{Al}_{2} \mathrm{O}_{3}$ pellets

Fluid: Synthetic

Geology: Limestone

gravel, "glass beads"

Configuration: $\mathrm{C} \rightarrow \mathrm{A}$

Anode: MMO

Cathode: $\mathrm{Fe}$

Catalyst: Pd

Fluid: Synthetic

Geology: Limestone block

Configuration:

Anode: Cast Fe

Cathode: $\mathrm{Cu}$

Catalyst: -

Fluid: Synthetic

Geology:-

Configuration: $\mathrm{A} \rightarrow \mathrm{C}$,

$\mathrm{C} \rightarrow \mathrm{A}$

Anode: MMO

Cathode: $\mathrm{MMO}$

Catalyst: $\mathrm{Pd} / \mathrm{Al}_{2} \mathrm{O}_{3}$ pellets

Fluid: Synthetic

Geology: -

Configuration: $\mathrm{C} \rightarrow \mathrm{A}$

Anode: MMO

Cathode: $\mathrm{Fe}, \mathrm{Ni}, \mathrm{Cu}, \mathrm{C}, \mathrm{Al}$
15-120 mA TCE Cast iron anodes enhanced TCE removal. The threeelectrode configuration further enhanced the removal. Lower flow rate enhanced removal, exceeding $82.2 \%$. Correlation between current density and influent concentration with upper threshold for current on removal.

30-90 mA TCE Increased electrode spacing and flow rate reduced the removal efficiency. Higher surface area (foam) improved conversion of TCE. Removal rates at 60 $\mathrm{mA}$ exceeded those at 30 and $90 \mathrm{~mA}$. C-C-A and Pd coating significantly increased removal rates and efficiencies. $>99 \%$ removal of TCE was achieved.

$60 \mathrm{~mA}$ TCE Presence of Fe(II) significantly enhanced TCE removal through Fenton reaction. Addition of sulfite improved TCE removal due to transformation into $\mathrm{SO}_{4}{ }^{-}$, reaching a removal efficiency of $71 \%$. Fouling of Pd by sulfide was assessed and found insignificant.

$60 \mathrm{~mA}$ TCE Presence of humic substance (HS) reduced TCE removal in a linear relationship. HS influenced the electrochemical processes of the cathode. TCE degradation in limestone without HS reached 82.9 $\%$, which was superior to that in glass beads.

$90 \mathrm{~mA}$ TCE Humic acids decreased TCE removal to $80 \%$ compared to a $90 \%$ removal in the control test, dichromate to $53-70 \%$, selenate to $76-89 \%$, while nitrate to $81-91 \%$. A mixture of the latter three contaminants reduced TCE removal to around 40 $\%$. The limestone block enhanced removal of TCE when compared to an acrylic column.

30-120 mA TCE Configuration of C-A was superior in performance to A-C with TCE removal of $54.5 \%$ and $34.8 \%$, respectively. Polarity reversal enhanced the removal to $69.3 \%$. Optimal design of polarity reversal for TCE removal was 15 cycles $^{-1}$ at $60 \mathrm{~mA}$ resulting in a power consumption of $13 \mathrm{~W} \mathrm{~cm}^{-2}$.

30-90 mA TCE

Highest removal was obtained with foam cathodes of $\mathrm{Ni}>\mathrm{C}>\mathrm{Cu}>\mathrm{Fe} \sim \mathrm{Al}$. $60 \mathrm{~mA}$ DC was most efficient. Removal with $\mathrm{Fe}$ foam increased from $43.5 \%$ to $99.8 \%$ when coated with Pd. Upper threshold existed for removal vs. Pd loading. Coating changed
[5] 
Catalyst: Pd

Fluid: Synthetic

Geology: -

Configuration: $\mathrm{C} \rightarrow \mathrm{A}$

Anode: $\mathrm{C}$

Cathode: $\mathrm{C}$

Catalyst: -

${ }^{1}$ A-C: Anode and cathode

$2 \rightarrow$ : Flow direction

${ }^{3}$ MMO: Mixed metal oxide coating on titanium

60-120 mA cathode material performance $\mathrm{Fe}>\mathrm{Cu}>\mathrm{C}>\mathrm{Al}>\mathrm{Ni}$.

Nitrates negatively influenced the removal.

TCE

Monopolar mode resulted in TCE removal of $29 \%$.

Introducing two bipolar electrodes increased removal to $66 \%$ due to enhanced peroxide formation. In bipolar mode, a current of $120 \mathrm{~mA}$ enhanced the removal, while highest current efficiency was obtained for $60 \mathrm{~mA}$.

Based on Table 1, knowledge gaps have been identified:

- Method efficiency in the degradation from the parent compound PCE to harmless ethenes

- Effects of the sandy aquifer geology on the electrochemical processes, degradation etc.

- Significance of field-extracted contaminated groundwater on method performance; influence of naturally occurring geochemistry and aged contamination at natural groundwater temperatures

- The role of iron purity of cathodes on degradation in view of commercial application cost

- The true feasibility of the method: In situ implementation and assessment of the method including up-scaling challenges, power consumption etc.

This study is part of an industrial $\mathrm{PhD}$ addressing these challenges and developing systems for optimisation of plume control by electrochemical zones in complex natural settings. A multidisciplinary study involving industry experts from; $C O W I A / S$, researchers from; DTU, GEUS and $U S A C E$, and a public authority and problem-owner; $C R D$.

The focus of the present paper is on the added complexity of operation under near natural settings compared to state-of-the-art simplified laboratory experiments. Thus, emphasis is on the influence of site characteristics and not on contaminant degradation efficiency. For this purpose, an undivided 1D-experimental column set-up is studied for assessment of electrochemical zones established within a sandy material saturated with site-extracted contaminated groundwater.

\section{Materials and methods}

An acrylic column set-up was designed for 1D-tests on electrochemical zones in natural settings (Figure 1). The dimensions were chosen such, that the total sample volume to be extracted during each sampling round would account for less than $2 \%$ of the total water volume contained within the saturated porous matrix. Darcy velocities of $61 \mathrm{~m} /$ year $(0.28 \mathrm{ml} / \mathrm{min}), 122 \mathrm{~m} /$ year $(0.56$ $\mathrm{ml} / \mathrm{min})$ and $305 \mathrm{~m} /$ year $(1.4 \mathrm{ml} / \mathrm{min})$ were maintained by a Watson-Marlow qdos30 manual peristaltic pump. Contaminated groundwater was collected from primary aquifers at two PCE contaminated sites in Denmark. For low flow testing, the groundwater was collected in Skovlunde, while for medium and high flow testing, the groundwater was collected in Lyngby because of a decreasing yield in Skovlunde. The groundwater samples were stored in multi-layered $25 \mathrm{~L}$ Tedlar bags in a fridge at $5^{\circ} \mathrm{C}$. The contaminant composition of the groundwater from Skovlunde and Lyngby is shown in Table 2.

Table 2. Contaminant composition of the field-extracted groundwater from Skovlunde and Lyngby 


\begin{tabular}{lcc}
\hline Component & Skovlunde, DK & Lyngby, DK \\
\hline Tetrachloroethylene $[\mu \mathrm{g} / \mathrm{l}]$ & 27 & 12 \\
Trichloroethylene $[\mu \mathrm{g} / \mathrm{l}]$ & 69 & 27 \\
1,1-dichloroethylene $[\mu \mathrm{g} / 1]$ & 0.06 & 0.29 \\
Cis-1,2-dichloroethylene $[\mu \mathrm{g} / 1]$ & 86 & 65 \\
Trans-1,2-dichloroethylene $[\mu \mathrm{g} / 1]$ & 0.81 & 1.4 \\
Vinyl chloride $[\mu \mathrm{g} / \mathrm{l}]$ & $<0.05$ & 1.3 \\
$1,1,1$-trichloroethane $[\mu \mathrm{g} / 1]$ & $<0.05$ & $<0.05$ \\
1,1-dichloroethane $[\mu \mathrm{g} / 1]$ & $<0.05$ & $<0.05$ \\
1,2-dichloroethane $[\mu \mathrm{g} / 1]$ & $<0.05$ & $<0.05$ \\
Chloroethane $[\mu \mathrm{g} / 1]$ & $<0.05$ & $<0.05$ \\
Tetrachloromethane $[\mu \mathrm{g} / 1]$ & $<0.05$ & $<0.05$ \\
Trichloromethane $[\mu \mathrm{g} / \mathrm{l}]$ & $<0.05$ & $<0.05$ \\
1,4-dioxane $[\mu \mathrm{g} / \mathrm{l}]$ & $<10$ & $<10$ \\
\hline
\end{tabular}

Volatile organic carbons were measured by Eurofins, Denmark using a Teledyne Texmar Atomx Purge \& Trap system with Vocarb 3000 trap followed by an Agilent 7890 GC with Agilent 5977 MSD equipped with a DB-624 Ultra Inert $1 \mu \mathrm{m}$ FT column (ID $0.18 \mathrm{~mm}$ x $20 \mathrm{~m}$ ). Hydrocarbons were measured by Eurofins, Denmark using an Agilent 6890 GC-FID and CTC headspace sampler equipped with a HP-PLOT Q $40 \mu \mathrm{m}$ FT column (ID $0.53 \mathrm{~mm} \times 15 \mathrm{~m}$ ). Analysis of anions was conducted on a Thermo Scientific Dionex ICS-1100 equipped with an AS14A column using an eluent of $\mathrm{Na}_{2} \mathrm{CO}_{3} / \mathrm{NaHCO}_{3}$ at a flow rate of $1.0 \mathrm{ml} / \mathrm{min}$. Cation analysis was measured on a Varian ICP-EOS 720-ES. Alkalinity was determined by Gran titration using $0.02 \mathrm{M} \mathrm{HNO}_{3}$.

The column was loaded with unrefined, excavated sandy aquifer material collected in Svogerslev sand quarry, Denmark (characterisation according to Table 3). To separate the sand from the electrodes, perforated PTFE cover plates were installed on each side of the electrodes to simulate well screens.

Table 3. Characterisation of the sandy aquifer material from Svogerslev, Denmark

\begin{tabular}{lll}
\hline Parameter & \multicolumn{2}{c}{ Method/Apparatus } \\
\hline Porosity $[\%]$ & 31 & Volume readings and weight measures \\
Grain density $\left[\mathrm{g} / \mathrm{cm}^{3}\right]$ & 2.57 & DS/CEN ISO/TS 17892-3 \\
Conductivity $^{1}[\mu \mathrm{S} / \mathrm{cm}]$ & 82.5 & Radiometer CDM210 probe measure \\
$\mathrm{pH}^{1}[-]$ & 8.62 & Radiometer PHM220 probe measure \\
Carbon content $[\%]$ & 0.952 & LECO Induction Furnace CS-200 \\
Sulphur content [\%] & 0.007 & prVI 99-11:2013 \\
Chalk content $[\%]$ & 15 & Laser diffraction; Malvern Instruments \\
$\mathrm{d}(0.1)[\mathrm{mm}]$ & 0.198 & \\
$\mathrm{~d}(0.5)[\mathrm{mm}]$ & 0.407 & Scirocco 2000 and Mastersizer 2000 \\
$\mathrm{d}(0.9)[\mathrm{mm}]$ & 0.895 &
\end{tabular}

${ }^{1}$ Measured in the aqueous phase of $10 \mathrm{~g}$ dry sand mixed with $25 \mathrm{ml}$ demineralised water for an hour at 215 rounds per minute

The electrode configuration comprised two pure iron cathodes and a downstream cast iron anode (Table 4), because two cathodes have shown to more than double the reaction kinetics [6]. The electrode rods $(6.35 \mathrm{~mm} \times 130 \mathrm{~mm})$ were mounted at $22.3 \mathrm{~cm}, 39.9 \mathrm{~cm}$ and $73.5 \mathrm{~cm}$. This electrode spacing was chosen to i) be able to separate and identify the mechanisms occurring at each electrode via analysis of extracted water samples having a limited impact of dragging towards the sampling points, ii) be able to assess the longitudinal extend of influence of each electrode's specific electrochemistry, and iii) accommodate the desire of increased electrode spacing during 
field-implementations to reduce costs, where the electrode spacing in the literature published is usually limited to a few centimeters. The cathodes were coated with $\mathrm{Pd}$ acquired from Thermo Fisher Scientific as $99.9 \%$ crystalline $\mathrm{PdCl}_{2}$. Palladization followed the procedure outlined in [11] for a loading of $0.76 \mathrm{mg} / \mathrm{cm}^{2}$ on Fe. A constant current intensity of $12 \mathrm{~mA}$ was applied over two cathodes and one anode using one Agilent E3612A 0-120V, 0-0.25 A power supply. The voltage was measured with a Hyelec MAS830B.

Table 4. Electrode specifications

\begin{tabular}{lcccccl}
\hline Electrode composition & C [\%] & Mn [\%] & P [\%] & S [\%] & Si [\%] & Supplier \\
\hline $99.8 \%$ soft ingot iron & $<0.02$ & $<0.08$ & $<0.02$ & $<0.015$ & - & GoodFellow, UK \\
Cast iron, EN-GJL-250 C & 3.25 & 0.77 & 0.148 & 0.066 & 2.39 & Tasso A/S, DK \\
\hline
\end{tabular}

Prior to the electrochemical test, the sand-filled column was saturated with the contaminated groundwater for two pore volumes (PV) at $0.56 \mathrm{ml} / \mathrm{min}$. In addition, the column was flushed for 2 $\mathrm{PV}$ at $1.4 \mathrm{ml} / \mathrm{min}$ in between concluded testing at one flow rate and continuation at the next higher flow rate. For each flow rate tested, sampling of pore water was conducted after $1 \mathrm{PV}$ and $2 \mathrm{PV}$.

\section{Results and discussion}

Only the data from the first round of measurements is shown for each flow rate. The trends were similar in the two periods. Included in the evaluation are $\mathrm{Cl}, \mathrm{F}, \mathrm{S}(\mathrm{VI}), \mathrm{N}(\mathrm{V}), \mathrm{Ca}, \mathrm{Fe}, \mathrm{Na}, \mathrm{K}, \mathrm{Mg}$, $\mathrm{Al}, \mathrm{Mn}, \mathrm{Ni}, \mathrm{Pb}$. The elements $\mathrm{P}, \mathrm{Cu}, \mathrm{Ba}, \mathrm{As}, \mathrm{Cd}, \mathrm{Cr}$ and $\mathrm{Zn}$ are not shown because of concentrations below detection limits.

\subsection{Geological properties}

The sand gave a high resistance for the flow of both water and current. The latter was expressed as a high voltage even at the low current intensity (127.8 $\mathrm{V}$ at $12 \mathrm{~mA}$, initially) (data not shown). The high resistance resulted in the three-electrode configuration operating as a two-electrode system, with the first cathode being passive. This is evident in Figure 2 and 3: Most parameters remained steady when passing the first cathode, while changes appeared on passing the second cathode. To manage this, two power supplies or e.g. rheostats must be incorporated to force the current through the geological media to each cathode. Such measures were taken for column studies in limestone gravel [5] and glass beads [6,7]. It has a further advantage of enabling control of the specific current supplied to each cathode. To maintain current control even with high electrical resistance in the system and to be able to increase the current density, a higher voltage DC supply must be applied.

In electrokinetics, an increase in $\mathrm{pH}$ at the cathode and a decrease at the anode is most often reported. In accordance, the $\mathrm{pH}$ reached levels exceeding 11 after the active cathode and decreased to around 6 at the anode (Figure 2).

\subsubsection{The carbonate system}

Water samples extracted near the second cathode had a milky colour. The ion analysis revealed a significant decrease in Ca here (Figure 3). According to Table 3, the sand was composed of $15 \%$ chalk, and the extracted groundwater showed significant $\mathrm{Ca}$ concentration (Figure 3 at $0 \mathrm{~cm}$ ). To obtain information on the carbonate system, alkalinity was measured in selected samples and from this total inorganic carbon (TIC) was calculated using the software PHREEQC [13] (Figure 4). The alkalinity indicated an active carbonate system with buffering of the acidity developed at the 
anode. Hence, compared to the $\mathrm{pH}$ of the inlet water, the insignificant decrease in $\mathrm{pH}$ near the anode can be attributed to the carbonate system. This impact of the groundwater chemistry is fortunate with respect to the commercial potential of the method, where highly acidic groundwater is undesirable. For longer durations, the buffering capacity of the system might become depleted, leading to acidic conditions near the anode. However, highly acidic conditions are not expected because of the reducing environment produced by iron anodes $[5,6]$.

The triggered changes in the carbonate system significantly altered the conductivity of the groundwater when Ca precipitated (Figure 2 and 3) and an effect from this deposition is clogging. However, in this study the dissolved Ca re-established near the anode, which indicated formation of colloids: Supersaturation of Ca-carbonate can result in the forming of Ca-carbonate colloids, which can move with the groundwater towards the anode, where the colloids then re-dissolve because of acid produced, thereby enhancing buffering. Concurrent dissolution of the chalk embedded in the sand is expected until depletion is reached. Clogging can affect the performance of the method, while formation of colloids is of little concern.

When Ca precipitates as calcite, $\mathrm{Mg}$ can be incorporated in the mineral structure [14]. This can explain the concurrent decrease in $\mathrm{Ca}, \mathrm{Mg}$ and TIC (Figure 3 and 4). Furthermore, exchange of cations on the mineral surface is likely [15]. Cation exchange appeared to influence the observed levels of $\mathrm{Mg}, \mathrm{K}, \mathrm{Na}$ and $\mathrm{Al}$ apparent for the flow rates tested (Figure 3). For Al, the changes could also be due to dissolution of Al-hydroxide stimulated by formation of aluminium hydroxyl complexes at the cathode and re-precipitation at the anode. Despite the significant alterations in groundwater chemistry resulting from cation exchange when considering the individual species $\mathrm{Mg}, \mathrm{K}, \mathrm{Na}$ and $\mathrm{Al}$, the overall impact of these cation exchanging species on the contaminant degradation is considered low, because the changes appear to be a side-effect of redox changes and not a direct competitive mechanism.

In the electrochemical system with iron electrodes, Pd catalyst and field-extracted groundwater, three overall chlorinated solvent removal mechanisms can occur: abiotic reduction utilizing hydrogen formed at the cathode (Eq. 1) [16] or $\mathrm{Fe}(0)$ (Eq. 2) [3,17], oxidation via reactive oxidative species like $\mathrm{OH}^{*}$ and $\mathrm{H}_{2} \mathrm{O}_{2}$ (Eq. 3(Eq. 4) [4], or sequential biotic reduction if a dechlorinating microbial culture like Dehalococcoides (Dhc) is present in the groundwater, which can benefit from the electrochemical formation of reducing conditions and hydrogen near the cathode (Eq. 5) [18]. Common for complete abiotic and biotic reduction is formation of ethene and/or ethane (Eq. 1(Eq. 2(Eq. 4(Eq. 5) [e.g. 4,5,19].

$$
\begin{gathered}
\mathrm{C}_{2} \mathrm{Cl}_{4}+5 \mathrm{H}_{2} \stackrel{\text { Pd }}{\rightarrow} \mathrm{C}_{2} \mathrm{H}_{6}+4 \mathrm{Cl}^{-}+4 \mathrm{H}^{+} \\
\mathrm{C}_{2} \mathrm{Cl}_{4}+\mathrm{Fe}^{0}+4 \mathrm{H}^{\cdot} \rightarrow \mathrm{C}_{2} \mathrm{H}_{4}+4 \mathrm{Cl}^{-}+\mathrm{Fe}^{2+}+2 \mathrm{e}^{-} \\
\mathrm{C}_{2} \mathrm{Cl}_{4}+4 \mathrm{OH}^{\cdot} \rightarrow 2 \mathrm{CO}_{2}+4 \mathrm{Cl}^{-}+4 \mathrm{H}^{+} \\
\mathrm{C}_{2} \mathrm{Cl}_{4}+2 \mathrm{H}_{2} \mathrm{O}_{2} \rightarrow 2 \mathrm{CO}_{2}+4 \mathrm{Cl}^{-}+4 \mathrm{H}^{+} \\
\mathrm{C}_{2} \mathrm{Cl}_{4}+2 \mathrm{H}_{2}+4 \mathrm{e}^{-} \stackrel{\text { Dhc }}{\rightarrow} \mathrm{C}_{2} \mathrm{H}_{4}+4 \mathrm{Cl}^{-}
\end{gathered}
$$

However, stoichiometry of the contaminant removal observed in this study is not sufficient in explaining the remarkably high levels of ethene and ethane measured in the pore water downstream 
the anode (Figure 5). Instead, this could form via electrochemical reduction of $\mathrm{CO}_{2}$ present as part of the carbonate system. The intermediate methane should then be formed near the cathode [20] and subsequently via polymerisation form ethane and ethene, possibly stimulated by anode processes [21]. Immediately downstream the second cathode, a low level of methane of $1.3 \mu \mathrm{mol} / \mathrm{l}$ was measured (data not shown).

\subsection{Sulphate}

The sand contained $0.007 \% \mathrm{~S}$ (Table 3$)$, possibly present as pyrite $\left(\mathrm{FeS}_{2}\right)$. Pyrite can be oxidised to $\mathrm{SO}_{4}$ and $\mathrm{Fe}$ (II) (Eq. 6) [22], which may occur in the oxidising zone near the anode and explain the increase in $\mathrm{SO}_{4}$ and $\mathrm{Fe}$ downstream the anode. However, possible presence of pyrite does not explain the decrease in $\mathrm{SO}_{4}$ in the reducing zone of the second cathode. Instead, reduction of $\mathrm{SO}_{4}$ to $\mathrm{S}(0)$ or $\mathrm{S}(-\mathrm{II})$ at the cathode followed by the reversed oxidation processes at the anode is expected (Eq. 7)(Eq. 8). That pyrite oxidation is not supplying the majority of $\mathrm{SO}_{4}$ is indicated by low levels or lack in detection of the common pyrite trace elements $\mathrm{Ni}, \mathrm{Pb}, \mathrm{As}$ and $\mathrm{Zn}$ (Figure 3) [23].

$$
\begin{gathered}
\mathrm{FeS}_{2}+3.5 \mathrm{O}_{2}+\mathrm{H}_{2} \mathrm{O} \rightarrow \mathrm{Fe}^{2+}+2 \mathrm{H}^{+}+2 \mathrm{SO}_{4}{ }^{2-} \\
\mathrm{SO}_{4}{ }^{2-}+2 \mathrm{H}^{+} \leftrightarrow \mathrm{S}_{(\mathrm{s})}+1.5 \mathrm{O}_{2}+\mathrm{H}_{2} \mathrm{O} \\
\mathrm{SO}_{4}{ }^{2-}+4 \mathrm{H}_{2} \leftrightarrow \mathrm{S}^{2-}+4 \mathrm{H}_{2} \mathrm{O}
\end{gathered}
$$

The $\mathrm{SO}_{4}$ concentration downstream the anode exceeded the inlet water concentration for the various flows by 3.1-17.2\% (Figure 2). This increase could be a combination of low-level pyrite oxidation and release of $\mathrm{S}$ from corrosion of the anode (Section 3.3). Presence of $\mathrm{S}$ can inhibit contaminant degradation caused by poisoning of the Pd catalyst [24]. However, the low-levels of $\mathrm{S}$ in this study possibly present from e.g. reduction of $\mathrm{SO}_{4}$ are considered of low impact [7,24].

\subsection{Corrosion of anode}

The impact of corrosion on the groundwater chemistry is dependent on the anode material applied. Corrosion of the cast iron anode likely released impurities embedded in the iron (Table 4). The measured mass loss (by weight) of the anode was $23 \%$ lower than the calculated mass loss from injected current. Based on the measured mass loss, the potential amount of Fe and Mn released during corrosion for the various flow rates exceeded the highest measured concentration of Fe and Mn downstream the anode with 56-1044\% and 98-197\%, respectively, indicating precipitation. Comparing corrosion levels with measured levels in the inlet water and detection of Fe and $\mathrm{Mn}$ in vicinity of the anode only, indicate that the main source of Fe and $\mathrm{Mn}$ was the corroding anode (Figure 3).

The potential release of S based on the measured mass loss of the anode for the flow rates studied constituted between $0.14-0.27 \%$ of the highest measured concentrations of sulfate downstream the anode (Figure 2). This contribution of $S$ to the increase in sulfate concentration downstream the anode when comparing with the inlet concentration, was only 1.5-5.3\%. Thus, the data suggest that anode corrosion was not the main source of $\mathrm{S}$.

Increasing the flow rate implied shortened duration between sampling rounds (for every $1 \mathrm{PV}$ ). Hence, less corrosion of the anode (as the current was unchanged) explain the lower concentrations of $\mathrm{Fe}$ and $\mathrm{Mn}$ detected with increasing flow rate (Figure 3 ). 
The effect of Fe release from corrosion is precipitation of iron oxides and/or iron hydroxides, and clogging. In early stages of the test, black deposits formed. With time, deposition expanded to cover the majority of sand located downstream the anode. Water samples extracted in this region had a grey transparent shade, which gradually changed to a red shade. Thus, these black deposits likely were wüstite $(\mathrm{FeO})\left(\right.$ Eq. 9)(Eq. 10) or magnetite $\left(\mathrm{Fe}_{3} \mathrm{O}_{4}\right)(\mathrm{Eq} .11)$ or green rust transformed from $\mathrm{Fe}(\mathrm{OH})_{2}$. Reactive iron minerals such as magnetite, pyrite and green rust may improve the abiotic dechlorination of chlorinated ethenes [25]. When the samples were transferred to vials with a headspace containing oxygen, the precipitates possibly oxidised to the $\operatorname{red} \mathrm{Fe}(\mathrm{OH})_{3}(\mathrm{Eq}$. 12). Concurrent with the precipitation of iron oxides, the pressure within the column rose and venting above the electrodes was increasingly challenging because of leakage of pore water. Thus, clogging caused by the iron precipitates is assumed important to the overall process.

$$
\begin{gathered}
\mathrm{Fe}^{2+}+2 \mathrm{OH}^{-} \rightarrow \mathrm{Fe}(\mathrm{OH})_{2(\mathrm{~s})} \\
\mathrm{Fe}(\mathrm{OH})_{2(\mathrm{~s})} \rightarrow \mathrm{FeO}_{(\mathrm{s})}+\mathrm{H}_{2} \mathrm{O} \\
6 \mathrm{FeO}_{(\mathrm{s})}+\mathrm{O}_{2} \rightarrow 2 \mathrm{Fe}_{3} \mathrm{O}_{4(\mathrm{~s})} \\
4 \mathrm{Fe}(\mathrm{OH})_{2(\mathrm{~s})}+\mathrm{O}_{2}+2 \mathrm{H}_{2} \mathrm{O} \rightarrow 4 \mathrm{Fe}(\mathrm{OH})_{3(\mathrm{~s})}
\end{gathered}
$$

The contribution of reactive iron minerals to the chlorinated solvent removal can not compensate for the practical issues experienced in laboratory set-ups arising from clogging. In the field, the conclusion may be different in that the system studied is not closed, wherefore issues with leaking and altered pressure is of less concern. For lab-studies, it is suggested to apply dimensionally stable anodes like MMO (Table 1). However, the reducing zone favoring dechlorination will be shortened and more oxygen will be generated at the anode when replacing the anode of cast Fe with MMO [26]. Gas bubbles in the pore space may also lead to decreased permeability leading to elevated pressure and leaking if no adequate means of venting is installed.

\subsection{Site-extracted contaminated groundwater}

Performing tests with contaminated site groundwater adds complexity besides the solution chemistry, since it contains chlorinated degradation products (Table 2). Hence, the design of the test must cope with the diverse composition of contamination, each component having a unique half-cell reaction potential [27,28]. Furthermore, the net reactions stimulated will complicate the interpretation of the parameters studied.

Working with field-extracted contaminated groundwater for testing of remediation also challenges the comparability of each study conducted because of fluctuations in contaminant composition, groundwater composition and concentrations of the ionic species and contaminant components on site. For the electrochemical remediation, this means a variation in redox reactions competing with the hydrodechlorination. Hence, ongoing adjustments of the applied specifications may be needed. In addition, the yield of the groundwater supply from one site can change over time and result in a need for a complete change of site (Section 2).

\subsection{Hydrology}


For the flow rates studied, insignificant alterations in trends of the recorded groundwater chemistry components were observed (Figure 2 and 3 ). The main effect observed when varying flow rates was the changing release of corrosion products from the anode resulting from these being a function of the constant current input (Section 3.3). The contaminant removal decreased with increasing flow rate (Figure 5) possibly due to the shorter residence time [5] or lower mass loss of the volatile contaminants at higher flow rates. Analysis of the gas phase extracted above the electrodes indicated a trend of less volatilisation with increasing flow (data not shown).

Performing electrochemical experiments at near natural groundwater temperatures possibly further challenges the removal of the contaminants attributable to the nature of the degradation mechanisms for this technology: Dechlorination rates are mainly limited by chemical dependent factors such as chemisorption and rates of bond-breaking, which decrease with decreasing temperature [29]. One way to overcome this challenge may be extension of the treatment zone with installation of more electrodes for a prolonged retention time.

\subsection{PHREEQC model}

A simple equilibrium 1D model was defined in the geochemical software PHREEQC - a computer program for speciation, batch-reaction, one-dimensional transport, and inverse geochemical calculations, version 3 [13]. The inlet concentrations of the elements $\mathrm{Al}, \mathrm{As}, \mathrm{Ba}, \mathrm{Ca}, \mathrm{Cd}, \mathrm{Cl}, \mathrm{Cr}$, $\mathrm{Cu}, \mathrm{F}, \mathrm{Fe}, \mathrm{K}, \mathrm{Mg}, \mathrm{Mn}, \mathrm{Na}, \mathrm{N}(\mathrm{V}), \mathrm{Ni}, \mathrm{P}, \mathrm{Pb}, \mathrm{S}(\mathrm{VI})$ and $\mathrm{Zn}$ measured during the experimental work were used for the flushing solutions. To simulate the cathode, the $\mathrm{pH}$ was forced to increase by adding $\mathrm{RbOH}$ (12 mmol, $\mathrm{Rb}$ is not included in the ion-exchange) and the electron activity (pe) forced to decrease by adding $\mathrm{H}_{2}$ (6 mmoles). The anode was simulated by decreasing $\mathrm{pH}$ and increasing $\mathrm{Fe}^{2+}$ by adding $\mathrm{FeBr}_{2}$ (16 mmoles, $\mathrm{Br}$ is unreactive), while pe was increased by adding $\mathrm{O}_{2}$ (8 mmoles). The model uses the standard phreeqc.dat database, which includes all the measured ions in the model as well as relevant exchanger coefficients. Partial pressures are not considered as such; the $\mathrm{H}_{2}$ and $\mathrm{O}_{2}$ gasses added react immediately, leading to very low partial pressures of both. Though the model is an equilibrium model, kinetic effects have to some extent been included by fixing the saturation state of calcite, dolomite and magnetite at $\mathrm{SI}>0(\mathrm{SI}=\log (\mathrm{IAP} / \mathrm{K})) ; 0.74$, 0.89 and 10. In general, kinetic effects would lead to gradual rather than abrupt changes. The model output showed:

- Low levels of methane formed near the cathode from reduction of $\mathrm{CO}_{2}$

- Reduction of $\mathrm{SO}_{4}$ to $\mathrm{S}(-\mathrm{II})$ near the cathode followed by oxidation to $\mathrm{SO}_{4}$ at the anode

- A decrease in $\mathrm{Ca}, \mathrm{Mg}$ and TIC resulting from deposition of calcite

- Ion exchange of $\mathrm{K}$ leading to decreasing concentrations downstream of the cathode. The more complex pattern seen for Na was not reproduced

- Supersaturation and precipitation of magnetite near the anode possibly explaining the black iron precipitates

Hence, the simple model supports the interpretation of the analytical results of the water samples extracted during the experimental work.

3.7 Rating of parameter influence 
Based on the observations and data interpretations made on the performed test on electrochemical remediation of groundwater in natural settings, a rating of parameters affecting the execution of the methodology is proposed (Figure 6).

Experiences gained during the experimental work point to a strong influence of the geological properties and the corrosion of the anode on the execution of electrochemical laboratory testing (Figure 6). The challenges with a corroding iron anode can be overcome by use of dimensionally stable anodes, e.g. MMO, though more oxygen will be generated. The influence of the geology needs to be better understood to be able to engineer the system for application in various geologies and more complex geological matrices. For calcium rich geologies, i.e. limestone aquifers, elevated calcium precipitation on the cathode may be experienced, which can be overcome by exhausting the buffering capacity through addition of acid to the well containing the cathode. For geologies containing a fraction of charged soil particles, e.g. clay particles, the additional transport mechanism electroosmosis may establish, which introduces a flow directed towards the cathode. In addition, heterogeneous geologies likely have a non-uniform electrical conductivity distribution and thereby varying resistivities. In between a pair of electrodes, the electrical current is expected to travel through the least resistive fractions of the soil matrix. Thus, it will be important to get the conceptual model of a site right and to continue research on applied electrochemistry for improved knowledge on the influence of site-specific parameters. The influence of less significant parameters is easily blurred by the alterations from more significant parameters. Hence, Figure 6 is not the complete picture.

\section{Conclusions}

The performed 1D-column study revealed a high complexity in electrochemical remediation of site-extracted contaminated groundwater in a sandy aquifer material. Further complication was attributed to corrosion of the cast iron anode because of e.g. precipitation. The complex system was modelled in a simple geochemical PHREEQC model, which was able to capture the main observed system responses to changes in $\mathrm{pH}$ and pe. Hence, the simple model could be used to assist in the understanding of the coupled geochemical processes. Based on the experiences gained, the significances of system parameters on the execution of electrochemical remediation in natural settings were ranked, with geology and anode corrosion being most important. Further work will address the observed challenges to optimize the method performance for in situ plume control.

\section{Acknowledgements}

This work was funded by the Innovation Fund Denmark [grant number 5016-00165B], COWIfonden [grant number C-131.01], the Capital Region of Denmark [grant number 14002102], COWI A/S and Technical University of Denmark.

\section{References}

[1] J.F. Pankow, S. Feenstra, J.A. Cherry, M.C. Ryan, Dense chlorinated solvents in groundwater: Background and history of the problem, in: J.F. Pankow, S. Feenstra (Eds.), Dense chlorinated solvents and other DNAPLs in groundwater, Waterloo Press, Oregon, 1996, pp. 1-52.ISBN: 9780964801417.

[2] A.M. Ruder, Potential health effects of occupational chlorinated solvent exposure, Ann. N. Y. Acad. Sci. 1076 (2006) 207-227. http://dx.doi.org/10.1196/annals.1371.050.

[3] J. Wang, J. Farrell, Investigating the role of atomic hydrogen on chloroethene reactions with iron using tafel analysis and electrochemical impedance spectroscopy, Environ. Sci. Technol. 37 (2003) 3891-3896. http://dx.doi.org/10.1021/es0264605. 
[4] S. Yuan, X. Mao, A.N. Alshawabkeh, Efficient degradation of TCE in groundwater using Pd and electro-generated $\mathrm{H} 2$ and $\mathrm{O} 2$ : A shift in pathway from hydrodechlorination to oxidation in the presence of ferrous ions, Environ. Sci. Technol. 46 (2012) 3398-3405. http://dx.doi.org/10.1021/es204546u.

[5] X. Mao, S. Yuan, N. Fallahpour, A. Ciblak, J. Howard, I. Padilla, R. Loch-Caruso, A.N. Alshawabkeh, Electrochemically induced dual reactive barriers for transformation of TCE and mixture of contaminants in groundwater, Environ. Sci. Technol. 46 (2012) 12003-12011. http://dx.doi.org/10.1021/es301711a.

[6] L. Rajic, N. Fallahpour, A.N. Alshawabkeh, Impact of electrode sequence on electrochemical removal of trichloroethylene from aqueous solution, Appl. Catal. B: Environ. 174-175 (2015) $427-434$. http://dx.doi.org/10.1016/j.apcatb.2015.03.018.

[7] S. Yuan, M. Chen, X. Mao, A.N. Alshawabkeh, A three-electrode column for Pd-catalytic oxidation of TCE in groundwater with automatic pH-regulation and resistance to reduced sulfur compound foiling, Wat. Res. 47 (2013) 269-278. http://dx.doi.org/10.1016/j.watres.2012.10.009.

[8] L. Rajic, N. Fallahpour, R. Nazari, A.N. Alshawabkeh, Influence of humic substances on electrochemical degradation of trichloroethylene in limestone aquifers, Electrochim. Acta 181 (2015) 123-129, DOI: 10.1016/j.electacta.2015.03.121.

[9] N. Fallahpour, X. Mao, L. Rajic, A.N. Alshawabkeh, Electrochemical dechlorination of trichloroethylene in the presence of natural organic matter, metal ions and nitrates in a simulated karst media, J. Environ. Chem. Eng. 5 (2017) 240-245, DOI: 10.1016/j.jece.2016.11.046.

[10] L. Rajic, N. Fallahpour, S. Yuan, A.N. Alshawabkeh, Electrochemical transformation of trichloroethylene in aqueous solution by electrode polarity reversal, Wat. Res. $67 \quad(2014) \quad 267-275$. http://dx.doi.org/10.1016/j.watres.2014.09.017.

[11] L. Rajic, N. Fallahpour, E. Podlaha, A. Alshawabkeh, The influence of cathode material on electrochemical degradation of trichloroethylene in aqueous solution, Chemosphere 147 (2016) 98-104. http://dx.doi.org/10.1016/j.chemosphere.2015.12.095.

[12] L. Rajic, R. Nazari, N. Fallahpour, A.N. Alshawabkeh, Electrochemical degradation of trichloroethylene in aqueous solution by bipolar graphite electrode, J. Environ. Chem. Eng. 4 (2016) 197-202. http://dx.doi.org/10.1016/j.jece.2015.10.030.

[13] D.L. Parkhurst, C.A.J. Appelo, Description of input and examples for PHREEQC version 3 - A computer program for speciation, batch-reaction, one-dimensional transport, and inverse geochemical calculations: U.S. Geological Survey Techniques and Methods, 2013, book 6, chap. A43, pp. 497. Available only at http://pubs.usgs.gov/tm/06/a43.

[14] C.A.J. Appelo, D. Postma, Carbonates and carbon dioxide, in: C.A.J. Appelo, D. Postma (Eds.), Geochemistry, groundwater and pollution, second edition, CRC Press, Taylor \& Francis Group, Leiden, 2005, pp. 176-240. ISBN10: 0415364280 .

[15] C.A.J. Appelo, D. Postma, Ion exchange, in: C.A.J. Appelo, D. Postma (Eds.), Geochemistry, groundwater and pollution, second edition, CRC Press, Taylor \& Francis Group, Leiden, 2005, pp. 242-309. ISBN10: 0415364280.

[16] W.W. McNab, R. Ruiz, Palladium-catalyzed reductive dehalogenation of dissolved chlorinated aliphatics using electrolytically-generated hydrogen, Chemosphere 37 (1998) 925-936. http://dx.doi.org/10.1016/S00456535(98)00095-2.

[17] W.A. Arnold, A.L. Roberts, Pathways and kinetics of chlorinated ethylene and chlorinated acetylene reaction with Fe(0) particles, Environ. Sci. Technol. 34 (2000) 1794-1805. http://dx.doi.org/10.1021/es980252o.

[18] F. Aulenta, L. Tocca, R. Verdini, P. Reale, M. Majone, Dechlorination of trichloroethene in a continuous-flowb bioelectrochemical reactor: Effect of cathode potential on rate, selectivity, and electron transfer mechanisms, Environ. Sci. Technol. 45 (2011) 8444-8451. http://dx.doi.org/10.1021/es202262y.

[19] X. Mao, J. Wang, A. Ciblak, E.E. Cox, C. Riis, M. Terkelsen, D.B. Gent, A.N. Alshawabkeh, Electrokineticenhanced bioaugmentation for remediation of chlorinated solvents contaminated clay, J. Hazard. Mater. 213-214 (2012) 311-317. http://dx.doi.org/10.1016/j.jhazmat.2012.02.001.

[20] M. Azuma, K. Hashimoto, M. Hiramoto, Electrochemical reduction of carbon dioxide on various metal electrodes in low-temperature aqueous $\mathrm{KHCO}_{3}$ media, J. Electrochem. Soc. $137 \quad$ (1990) 1772-1778. http://dx.doi.org/10.1149/1.2086796.

[21] S. Petrovic, J.C. Donini, S.S. Thind, S. Tong, A.R. Sanger, Electrochemical conversion of hydrocarbons, US006294068B1 (2001).

[22] C.A.J. Appelo, D. Postma, Redox processes, in: C.A.J. Appelo, D. Postma (Eds.), Geochemistry, groundwater and pollution, second edition, CRC Press, Taylor \& Francis Group, Leiden, 2005, pp. 415-487. ISBN10: 041536428 0 . 
[23] M.K. Baruah, P. Kotoky, G.C. Borah, Geochemical association of Ni2+, $\mathrm{Zn} 2+, \mathrm{Pb} 2+, \mathrm{Ag}+, \mathrm{Cu} 2+$, and $\mathrm{CO} 2+$ ions in natural pyrite, J. Geochem. 2014 (2014) 1-20. http://dx.doi.org/10.1155/2014/161850.

[24] S. Yuan, M. Chen, X. Mao, A.N. Alshawabkeh, Effects of reduced sulfur compounds on Pd-catalytic hydrodechlorination of trichloroethylene in groundwater by cathodic $\mathrm{H}_{2}$ under electrochemically induced oxidizing conditions, Environ. Sci. Technol. 47 (2013) 10502-10509. http://dx.doi.org/10.1021/es402169d.

[25] Y.T. He, J.T. Wilson, C. Su, R.T. Wilkin, Review of abiotic degradation of chlorinated solvents by reactive iron minerals in aquifers, Groundw. Monit. Remediat. 35 (2015) 57-75. http://dx.doi.org/10.1111/gwmr12111.

[26] N. Fallahpour, S. Yuan, L. Rajic, A.N. Alshawabkeh, Hydrodechlorination of TCE in a circulated electrolytic column at high flow rate, Chemosphere 144 (2016) 56-64. http://dx.doi.org/10.1016/j.chemosphere.2015.08.037.

[27] T.H. Wiedemeier, H.S. Rifai, C.J. Newell, J.T. Wilson, Overview of intrinsic bioremediation, in: T.H. Wiedemeier, H.S. Rifai, C.J. Newell, J.T. Wilson (Eds.), Natural attenuation of fuels and chlorinated solvents in the subsurface, John Wiley \& Sons, Inc., New York, 1999, pp. 162-188. ISBN: 9780471197492.

[28] A.L. Roberts, L.A. Totten, W.A. Arnold, D.R. Burris, T.J. Campbell, Reductive elimination of chlorinated ethylenes by zero-valent metals, Environ. Sci. Technol. 30 (1996) 2654-2659. http://dx.doi.org/10.1021/es9509644.

[29] T. Li, J. Farrell, Electrochemical investigation of the rate-limiting mechanisms for trichloroethylene and carbon tetrachloride reduction at iron surfaces, Environ. Sci. Technol. 35 (2001) 3560-3565. http://dx.doi.org/10.1021/es0019878. 


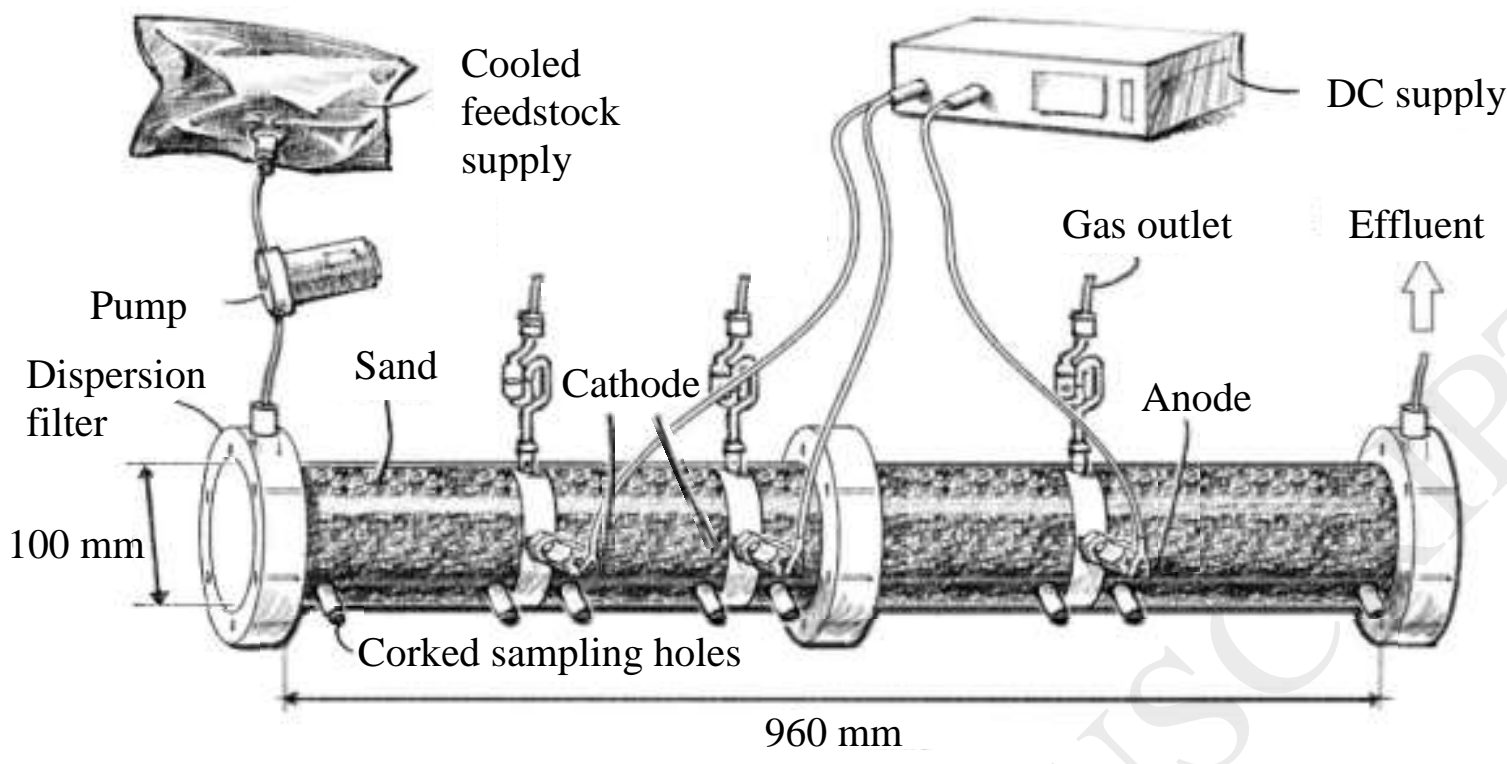

Figure 1. Sketch of the undivided flow-through electrochemical reactor loaded with sand. The feedstock supply illustrates the field-extracted contaminated groundwater stored at $5^{\circ} \mathrm{C}$. 

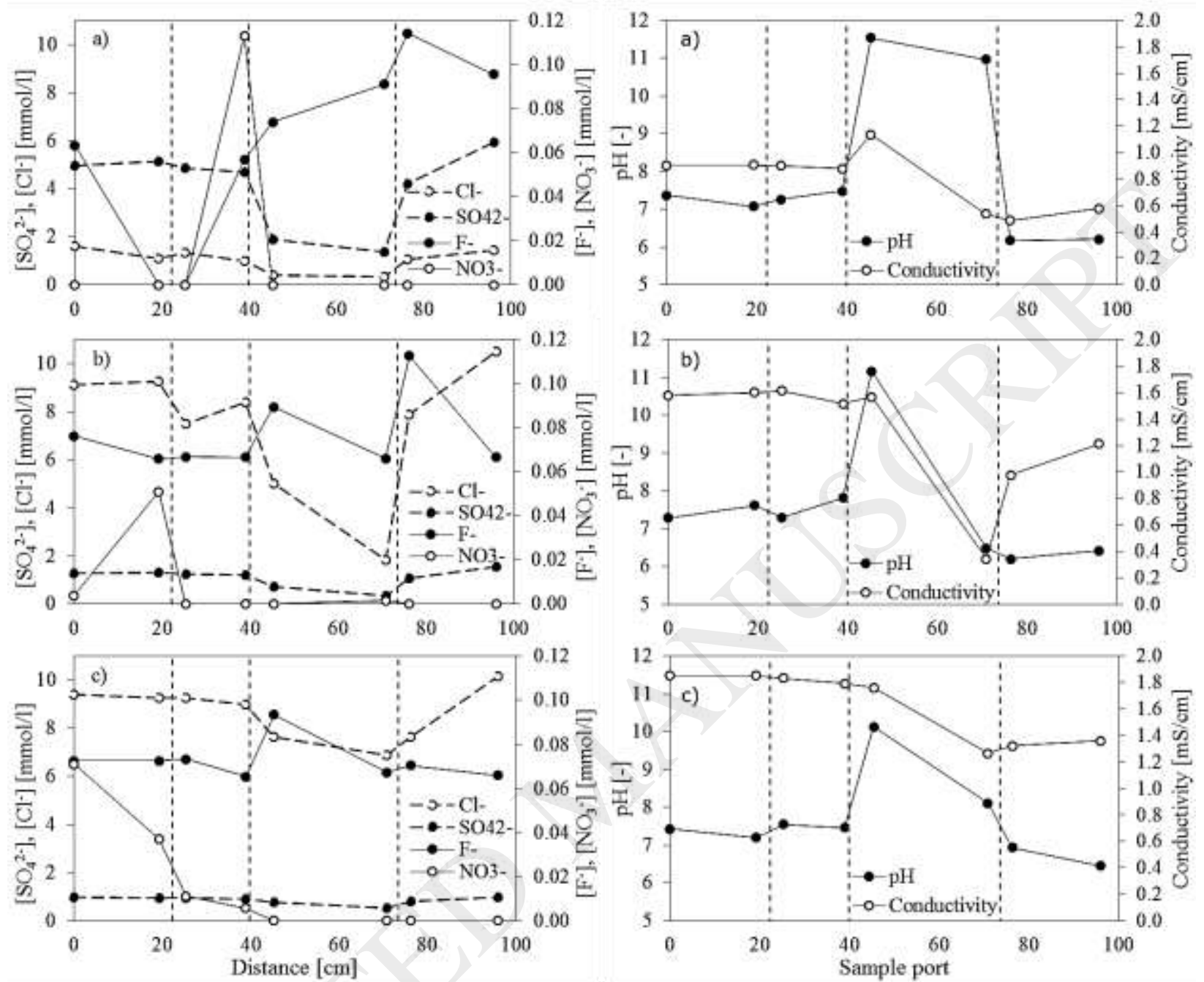

Figure 2. Concentrations of anions, $\mathrm{pH}$ and conductivity measured in the pore water throughout the sand loaded column for flow rates of a) $61 \mathrm{~m} /$ year $(0.28 \mathrm{ml} / \mathrm{min})$, b) $122 \mathrm{~m} /$ year $(0.56 \mathrm{ml} / \mathrm{min})$ and c) $305 \mathrm{~m} /$ year $(1.4 \mathrm{ml} / \mathrm{min})$. The dashed vertical lines indicate the position of the electrodes; two cathodes and a downstream anode, which were operated at $12 \mathrm{~mA}$ DC. Sampling occurred after $1 \mathrm{PV}$. Note, the contaminated groundwater used for (a) is of another origin than the groundwater used for the remaining tests. 

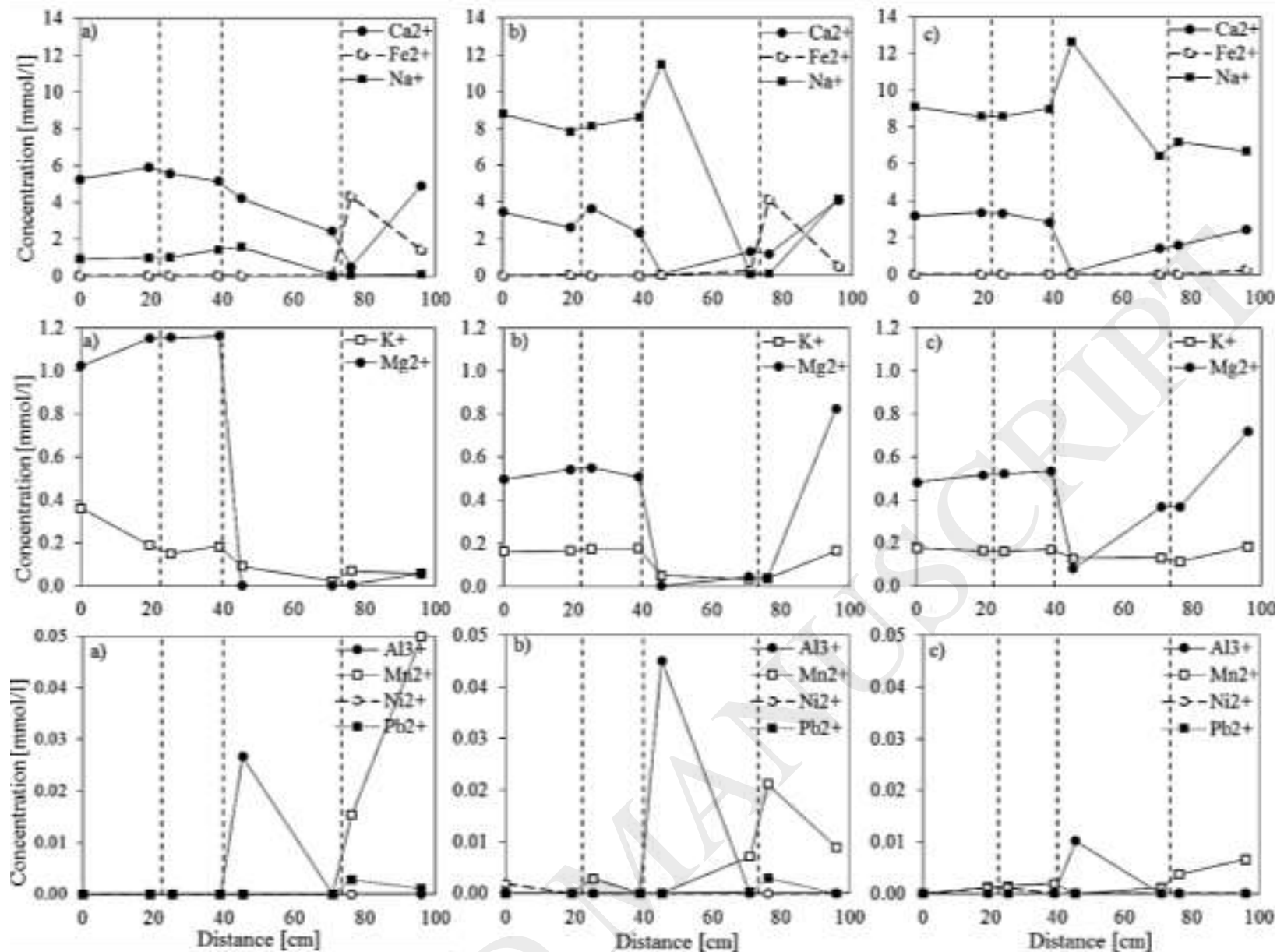

Figure 3. Concentrations of cations measured in the pore water throughout the sand loaded column for flow rates of a) $61 \mathrm{~m} /$ year $(0.28 \mathrm{ml} / \mathrm{min})$, b) $122 \mathrm{~m} /$ year $(0.56 \mathrm{ml} / \mathrm{min})$ and c) $305 \mathrm{~m} /$ year $(1.4 \mathrm{ml} / \mathrm{min})$. The dashed vertical lines indicate the position of the electrodes; two cathodes and a downstream anode, which were operated at $12 \mathrm{~mA} \mathrm{DC}$. Sampling occurred after $1 \mathrm{PV}$. Note, the contaminated groundwater used for (a) is of another origin than the groundwater used for the remaining tests. 


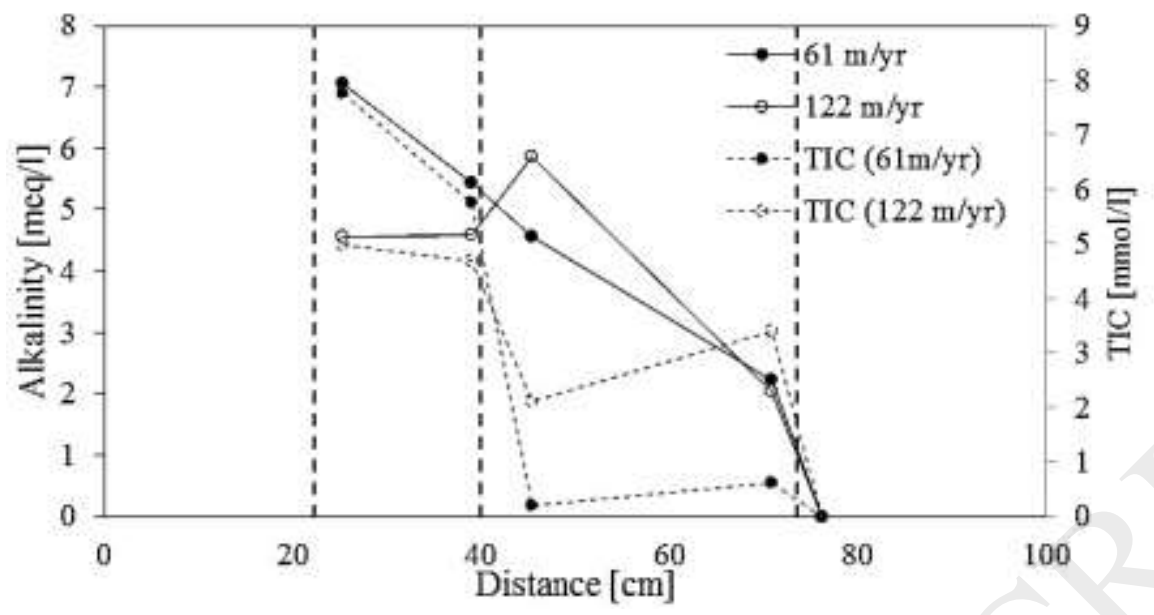

Figure 4. Alkalinity estimated based on Gran titration and TIC calculated using PHREEQC [12] in the pore water of the sand loaded column for selected samples of two flow rates; $61 \mathrm{~m} /$ year $(0.28 \mathrm{ml} / \mathrm{min})$ and $122 \mathrm{~m} /$ year $(0.56 \mathrm{ml} / \mathrm{min})$. The dashed vertical lines indicate the position of the electrodes; two cathodes and a downstream anode, which were operated at $12 \mathrm{~mA} \mathrm{DC}$. Sampling occurred after 1 PV. Note, the contaminated groundwater used for the two flow rates originated from different sites. 

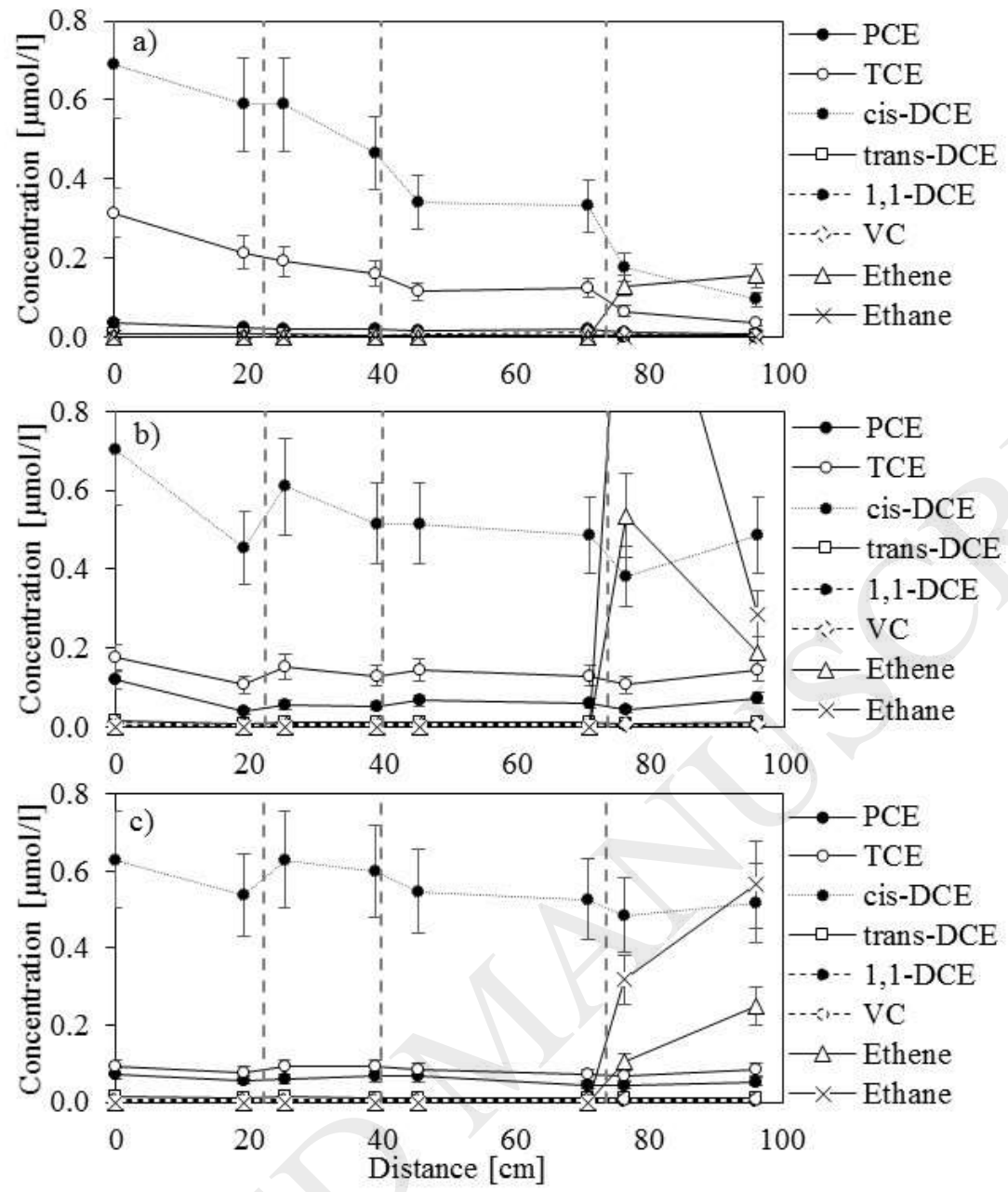

Figure 5. Contaminant concentrations measured in the pore water throughout the sand loaded column for flow rates of a) $61 \mathrm{~m} /$ year $(0.28 \mathrm{ml} / \mathrm{min})$, b) $122 \mathrm{~m} /$ year $(0.56 \mathrm{ml} / \mathrm{min})$ and c) $305 \mathrm{~m} /$ year $(1.4 \mathrm{ml} / \mathrm{min})$. The dashed vertical lines indicate the position of the electrodes; two cathodes and a downstream anode, which were operated at $12 \mathrm{~mA} \mathrm{DC}$. Sampling occurred after $1 \mathrm{PV}$. In b) the outlying data point for ethane is at $1.5 \mu \mathrm{mol} / \mathrm{l}$. Note, the contaminated groundwater used for (a) is of another origin than the groundwater used for the remaining tests. 


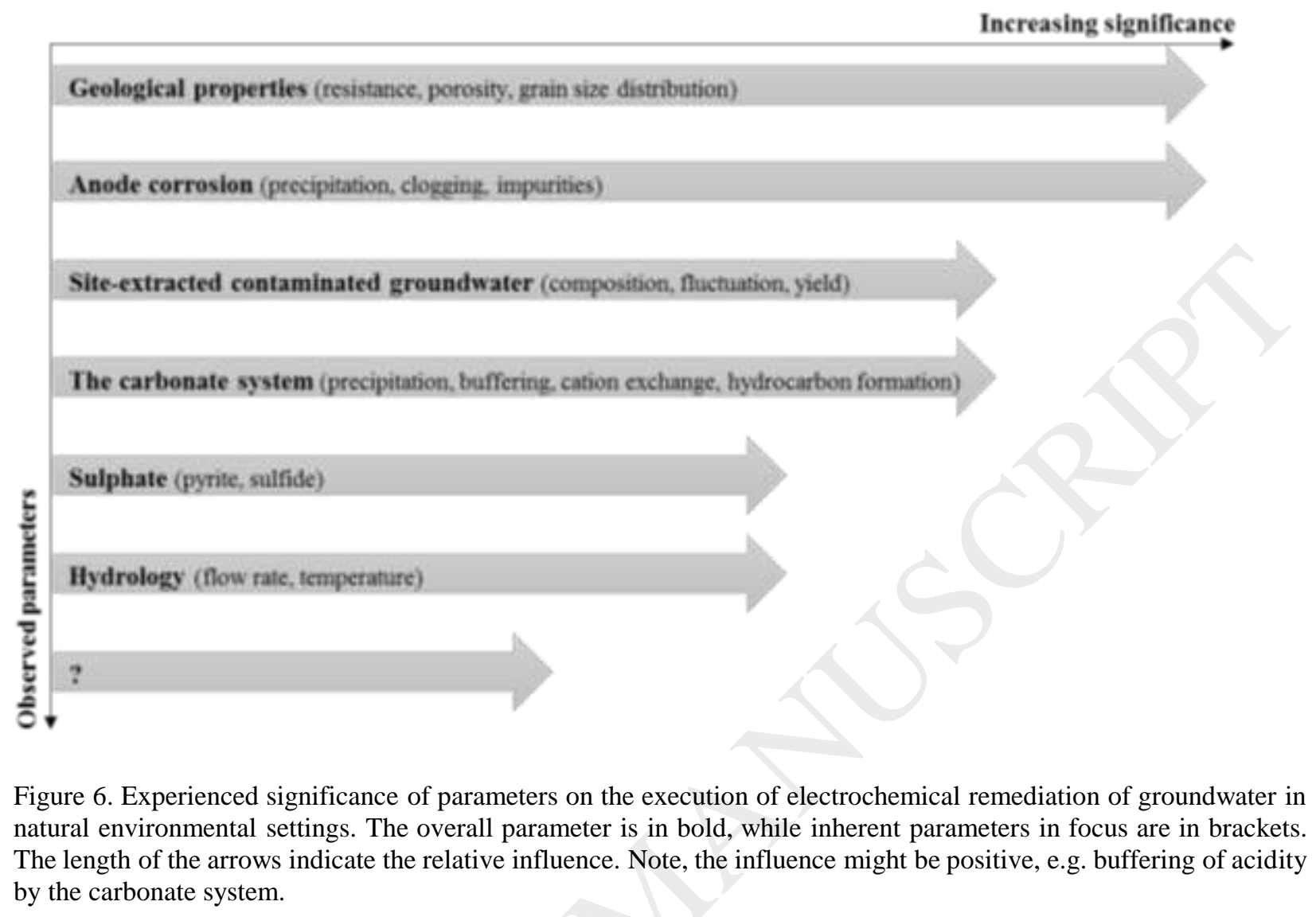

